\title{
Arabic Travelogue of Shaykh Ibrahim to Nigeria as In His Naynil-Mafāz: Translation and Appraisal
}

\author{
Dr. S.A. Shittu
}

\begin{abstract}
Travelogue played a vital role in developing Arabic Language and its culture in Africa especially during the medieval period. At this point in time Arabs and non-Arabs became adventurers who made tour to African countries at large and West Africa in particular. Such travelers include IbnBatūta, IbnKhaldūn, alBakri al-Mas'ūì̄ among others. Their documentation of events serves as a great treasure in preserving environment, state and culture of Islam in those countries visited. Shaykh Ibrahim al-Kawlakhi of Senegal'sNaylul-MafāzbilAwdiIlal-Hijāz is an excerpt from Majmū' al-Rihlātush Shaykh Ibrahim (The compendium of Shaykh Ibrahim's journey), it is a 71 lines poem rendering an account of his journey to Nigeria on his way to and from the Holy land for pilgrimage. This paper commences with a brief biographical account of the erudite Süfi poet, English translation of the poems precedes the content analysis of the poems. The poem is a comprehensive record of Sufi leaders in Nigeria, important eminence and even security men who joined his admirers in welcoming him with aura of dignity. His vivid description reveals love, kind gesture and rare hospitality received from his hosts. The influence of the poem on West Africa Sufi writers and adherents concludes the work.
\end{abstract}

\section{Introduction:}

Travelogue or travel literature typically records the experiences of an author touring a place for the pleasure of travel. Such literature may be cross-cultural or transnational in focus, or may involve travel to different regions within the same country ${ }^{1}$. It is a literary form that depends in its uniqueness upon the character and vision of the traveller more than the strangeness or remoteness of locality ${ }^{2}$. The traveller's consciousness represents the principal authority, an active point of energy that made sense not just of colonizing activities but of exotic geographies and peoples. ${ }^{3}$ It is thus seen as a document which reveals the traveller's own interests and the purposes behind his travels, in addition to being a record of what he witnesses in the different lands he visited $^{4}$. Travelogues are therefore collections of practical data about the countries the travellers visit and records of individual events, feelings, emotions, fears, and exceptional changes in dignified prose which inclines to moody artistry that depends on the writer's own viewpoint. ${ }^{5,6}$

The travel genre in the Arab Islamic culture has evolved into becoming an integral part in the creation of the modern Arabic literary forms in addition to being a medium of self-expression and identity. The travel genre or rahil in the poetic and narrative compositions of the pre-Islamic legendaries, such as the poets Imru alQays and 'Antaraibn-Shaddad, as well as, the poet and ascetic Umayah bin abi al-Salt, provide evidence as to the early use of the travel genre to articulate themes of individual, cultural, and religious magnitudes. Whereas the travel narratives of IbnJubayr, Ibn Battuta, and IbnKhaldun, employ the inherited actual and spiritual properties of the travel genre to describe and discern the state of the Islamic Ummah, or community, as well as their place in it, the Maqamas of the travelers al-Tahtawi, al-Shidyaq, and al-Muwaylihi, expanded the use of the genre to articulate intercultural dialogues on both individual and national levels. ${ }^{7}$

Shaykh Ibrahim Nyass al-Kawlakhi'sNaylul-Mafāz is a sub-title extracted from a book entitled:Majmū' al-Rihlätush Shaykh Ibrahim (The compendium of Shaykh Ibrahim's journey), ${ }^{\mathbf{8}}$ a versified documentation of his visit to the Holy lands through West African countries. Although, he paid several visits to Nigeria but the poems being analysed is specific to his experience with the Tijaniyyah Adherents in Kano and Lagos, Nigeria, during this trip.

\section{Shaykh Ibrahim Nyass al-Kawlakhi}

Shaykh Ibrahim b. AbdullāhiNyassbn Muhammad bnMadambabnBakribn Muhammad al-Amīnbn Samba bnRidā was born in the evening of Thursday after Asr prayer at TaybahNyass, a village near Kawlakh, Senegal in the middle of the month of Rajab 1320 A.H corresponding to the year 1900 C. $E^{9}$ to a renowned scholar, al-Hajj AbdullahiNyass. His mother was 'Aisha Bint Ibrahim. He grew up in a religious atmosphere and a healthy environment for learning and scholarship. His father settled down in Kawlakh in 1910. His father was known as a great scholar, a zealous revival of the Sunnah of the Prophet. Shaykh Ibrahim studied and memorized the Qur'ān under the tutelage of his father. He also studied other various branches of knowledge under him. ${ }^{10}$ 
He was a versatile scholar and a prolific writer. As many as seventy works have been attributed to him on various subjects including jurisprudence (figh), Arabic language and literature, Sufism, (tasawwuf), the life history of the Prophet (Sirah), etc. He was a poet of high repute who produced many anthologies. His motives for writing were multi-farious. As a Tijaniyyah leader, ${ }^{11}$ he wrote to explain the basic tenets of the Tariqah ${ }^{12}$ and to defend them. He also wrote to answer questions which were put to him by antagonists to these tenets or to defend his own claims or views as evident in his Raf 'ul-'Malam 'ammanrafa 'awaqabadaiqtida'biSayiddil'Anam which he wrote to defend his views on Qabd (folding of arms in prayer) and raising of hands at different postures in the prayer.

He delivered speeches in many international and local conferences majority of which were compiled by one of his disciples, Ahmad Barnawi, a native of Maiduguri, Nigeria under the title: JāwahirulRasā'il (Precious Epistles). ${ }^{13}$ His first literary work, Ruhul-Adab lima Hawā min HikaminwaAdab(1922),written at a tender age, states the expected ethics for a novice, Tariqah aspirants and leaders with the required spiritual training. ${ }^{14}$ In 1931, he produced his first extensive work titled Kashfu al-bas an Faydatil-KhatimiAbil-'Abbas where he demonstrated vast knowledge of Tasawwufespecially that of the Tijaniyyah order.

\section{English Translation Of Naylul-Maf $\square z$}

A Journey from Gambia to Kano

1. We apparently travelled from Sierra-Leone to Takurad, Ghana. I surely thank my God, who granted me (all) my need

2. Also, I was brought to Accra, and the situation, at the moment underwent changes

3. Then, the spirit of Shaykh Tijāni, the $q u t b^{15}$ of the existing creatures and the source of knowledge got aroused

4. I firstly stopped at Ahmad al-Futi's place, I prayed that may Allah continue (showering) his blessings on him as He is doing

5. For seeing me, he thanked Allah repeatedly for His good intentions in His servant (Shaykh Ibrahim)

6. I quickly saw that I do not deserve (this unprecedented respect) if not by Allah's support, and the covering up (of my inequities) by my Creator, the Generous and the Praiseworthy

7. Delegations visited me at subh time; on seeing me they believed they attained successes

8. I met Ya'qubMaigha (while) travelling at night, his good gesture is indeed worthy of mention

9. Likewise, Shaykh Salih and before any other person, Shaykh Hussayn is worthy of mention, who for my sake struggled with his best ability

10. Also in attendance is KijākhuShimah, the interpreter, who compiled my scattered scripts.

11. The mind yearned to be at Kumasi but the door to Hijāz (the Holy land) has been opened

12. I am indeed extending my best salutation to MuqaddamTharumi, our-in-law and our great lover

13. I also extend my regards to my brethren, my brothers-people of Kumasi; they are indeed my reliable friends.

B My Journey to Lagos

14. We boarded flight to Lagos chanting Dhikr (Supplication), to Allah Who brought (His prophet) from a nocturnal journey-

15. His servant (Prophet Muhammad) on a night from (a journey originating from) the sacred mosque (kaabah) to the mosque of al-Aqsā

16. I always feel comfortable whenever I meet Abdul-Majīd who sacrifices his time for me

17. People of Agege (Lagos, Nigeria) are really ideal; they remained honoured and beloved to us

18. I met the absence of Shaykh Sālih in Lagos, may the goodies of Allah extend to him whenever he returns

19. I passed through Zaria and I wished I could briefly stayed with them

20. I remembered their leader Shaykh Yahudha our friend, fortune is indeed for whoever studied under him

21. The third of the town (en route) is Katsina - a place of Shaykh Ja 'far, the place of an illuminating light

22. Shaykh Ilyās also met me in Katsina, paid homage of a person whose mind is illuminated with light

23. They are my friends and helpers: they ever remained in the flowing Faydah (glad tidings of Allah)

C The arrival at Kano

24. When the flight was about to reach Kano, my prayer was that Kano remain blessed forever

25. Indeed, what I never anticipated happened when I arrived Kano by Allah's protection

26. I was indeed convinced that Allah dispenses affairs as He wishes.

27. I started saying: where is that Shaykh to whom great men bowed

28. And who is Barham (Shaykh Ibrahim)? Who made them realize who Barham is? Such that they exhausted (their energy) for his love and affection 
29. By Allah, if not because I devoted all my life in Shaykh Ahmad Tijani entirely, I would have perished (forgotten for a long time).

30. Because, I am just lowly and a sinful servant; by Allah, I have not repented (from all my sins) and indeed (I am) a sinner

31. They do not know that they showed interest in a person who Allah covered his anomalies and exposed (only)the good side of him

32. I was heralded by Tharūmī (a prince), who embraced me tightly in a manner that was not all that convenient

33. I was held back by soldiers and (even) Christians in fear of what they envisaged (stampede and insecurity) for me

34. I was asked to returned to the plane until they could ascertained my security and beef up security

35. Returning with me (back to the plane) was Tharūmī, who (later) took me to his story building in the palace to make my mind settled

36. We slept and it was impossible for me to go out neither do the lovers had any access to come in

37. Unfortunately, Amir Abdullahi, (Sultan Ado Bayero of Kano) was already in the house of Allah

38. May the blessing of Allah be on the Amìr and his family, his endeavours and wealth

39. (To) His succeeding son (the vizier), Tharūmi -the great, who recited (the Qur'an), his recitation is precious to us

40. May Allah protect him from the enemies; may he be helped forever

41. He properly served me as he serves the Amir (The Emir). My admirer, Abubakr and Wazir-

42. Also came to me from Bornu, and al-Maraqi was a valued delegation who I love to meet

43. Among them were Muhammad and Musa. May Allah spare them from tribulation and destitute.

D Return from Jeddah to Kano through Khartum, Junayna and Maiduguri

44. When I boarded flight from Khartūm (Sudan), my sight of the physical objects seem blurred

45. I arrived at Junayna and Borno; (and) the eyes of my admirers to me became radiant

46. I flew through Borno praying for my admirers, the noble ones

E My Return to Kano after the Holy Pilgrimage

47. I arrived at Kano, where my admirers exist enjoying what the seal of the saints had enjoyed

48. A delegate came from Katsina: AmīrUthmān, judges and the Wazīr

49. They are powerful delegates for which we requested from Allah to grant them honour and elevation

50. Amī - Alh. Abdul-Malik arrived; the wonder of my Lord, a young religious servant

51. Shaykh Muhammad Gibrīm, ${ }^{16}$ a man of knowledge whom I found always showing interest in anything shining

52. He eulogized me, may Allah reward him with goodies here and hereafter; may he be protected from all tribulations

53. Yahya equally praised me (and) permission of becoming a Muqaddam was granted. I indeed permitted him

54. Likewise, (Shaykh Tāhir) a man of clean mind and good body praised me, in the beginning and end (of his poem)

F Journey form Kano to Kaolakh

55. I was out of Kano and my mind was still in Kano, why not? Since my admirers live in Kano

56. They lived peacefully in Kano and in hereafter they will live an elegant life in the paradise called ('Iliyyinn)

57. I was escortedby the Amīr and the soldiers; may Allah protect him (the Emir) from all evils thatharm (mankind)

58. Likewise, Muhammad Sanusi, the Amir's closest companion an abode which is meant for men of God is wished to him

59. Muhammad al-Galī was also present, a traveler -whom I granted permission to be a leader.His spiritual dedication was well affirmed

60. He is one of our righteous leaders, who has total commitment to our covenant with good disposition as usual

61. May Allah reward our Amīr for us (Abdullahi Ado Bayero). He is a respected servant of God. Indeed: He is great

62. May Allah reward my companion and admirer - Tharumi who is always on my mind

63. May Allah reward dwellers of other towns with the pleasure of the Beneficent on the land

64. I boarded in (Nigeria) a flight to return (to my destination) in the mood of seeking repentance from my Lord with the mind of hope and fear.

65. There (in Senegal), where the body resides and the admirers in the town, likewise the companions 
66. I say!My obligation to God of truth and this right cannot be claimed by any creature

G Passing by Lagos, on returning to Kaolack

67. I reached Lagos, it seemed as thoughI was still in Kano, due to many admirers who lived there

68. I saw Shaykh Sālihand ShaykhAbbās(the former who had arrived from his journey)Infact, people trooped out from every corner (of the region) to usher me

69. Were it not for the assistance of the soldiers, the danger envisaged to occur would have been serious but with their presence, it was averted

70. Our flight passed by the palace of Lome, O sister of Jimba! Do not accuse me for not branching (at the city)

71. I worship my God He granted the permission (of efficacy) to me. I peacefully returned (to my Home) with total delight

\section{Appraisal of Contents on His Way to Hajj:}

He described his flight from MadinaKaolack to Lagos with some references to Sufi leaders residing in Lagos who gave him a rousing welcome. These include Shaykh [Sherif] Abdul MajeedAgege and his followers. He also mentioned the absence of Shaykh Sālih of Lagos. From there, he took another flight to Kano. On his way to Kano, he mentioned the name of his admirers whom he would have loved to visit if the journey was not by air. Such people include Shaykh Yahūdha of Zaria, Shaykh Ja ‘far, and Shaykh Ilyās of Katsina. He prayed to Allah to continue His Blessings on Kano and its inhabitants.

The aura of dignity and rousing welcome he received on his arrival at Kano subjected him to think that it was too much for a humble servant of Allah who owns nothing to himself except what Allah bestows on him. He conclusively attributed this honour to his total submission to Allah, unquantifiable love for the Prophet and his commitment to the tenets of Shaykh Tijani's doctrine. The environment was somehow rowdy due to the happiness of the admirers to the extent that the vizier of the Emir of Kano - Tharumi had to hold him back at the tarmac and requested for police and soldier escort who made the exit from the airport and entrance into Emir's palace easier. This occasioned the mention of the commendable efforts of security men in the poem. It was stated how they averted unforeseen injury or danger which might have occurred to him and his admirers. The poet mentioned delegates who visited him in Kano and its neighbouring cities such as Shaykh Muhammad, Shaykh Musa from Borno and those from Maraqish.

\section{His Return from Hajj to Kano:}

He described how the flight passed through Khartoum, Borno and other cities before landing in Kano. He mentioned names of delegates and their leader who welcomed him in Kano, such include Shaykh Uthman Emir and Shaykh Gibrima from Nguru whom he prayed Allah to reward abundantly for his generous eulogy poured on him. Shaykh Yahya and Shaykh Tāhir also eulogized him and he prayed for them in return.

\section{His Departure from Kano to Kaolack:}

He commenced his composition in this part by showing deep appreciation to his admirers in Kano and how their kind gesture will continue to linger in his memory by saying: Although I departed from Kano temporally but my mind still remained in Kano. He mentioned those who saw him off to the airport namely: Shaykh Muhammad Sunūsī, Shaykh Muhammad al-GhālīTharūmi was especially mentioned for his wonderful reception.

\section{His arrival at Lagos en route Kaolack:}

He opened this section by not repeating himself, he briefly said: I came to Lagos and it seemed as if I was still in Kano because of the similarity of the rousing welcome. The return of Shaykh Salihu to Lagos from his journey was mentioned. Shaykh Abbās s warm reception was also acknowledged. He ended this part by describing the unexpected great numbers of people who trooped out from the different cities surrounding Lagos in the southwest of Nigeria.

Appraisal of Style:

He chose Bahrul-Rajaz in the composition of the poem. The analysis goes thus,

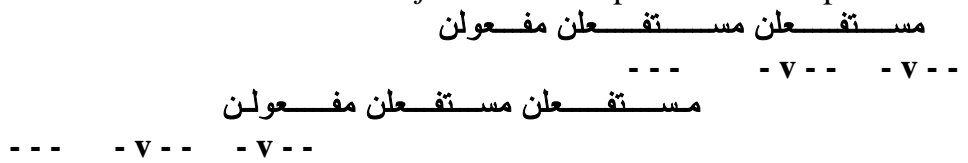

The metre was maqtu'u'rrajaz which accounted for the elision in Mustaf'ilun becomingmaf'ulun in both the 'arudand darb of the metre ${ }^{17}$. 
However, the style of West Africa Sufi writing was however, not employed. Such style includes starting with hamdalah, salsalah and ending it with salsalah. The reason could be adduced to the fact that this is just an excerpt extracted from an anthology, the whole which has contained those idiosyncrasies in the beginning and at the end.

The language of the poem is very simple, clear to a Sūfì and non- Sūfì adherents. The poems revealed the competence of the Süfi leader in rendering Arabic Language. He used very concise words to give a very powerful description of situation and environment such as:

\section{ردنى الجيوش و النّصارىخوفا عليّ وهم حيارى}

Meaning:

- I was held back by the soldiers and the Christians in fear of what they envisaged for me

He also exhibited that he has a lot in his lexicographical treasure. His use of Jinās (Pun) enriched the beautification of the poem. Such as:

Meaning:

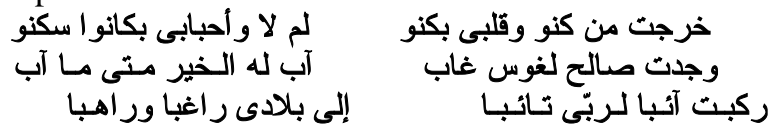

I was out of Kano and my mind was still in Kano, and why not? Since my admirers live in Kano

- I met the absence of Shaykh Sālih at Lagos, may the goodies of Allah extend to him whenever he returns

- I boarded a flight to return (home) in the mood of seeking repentance from my Lord with the mind of hope and fear.

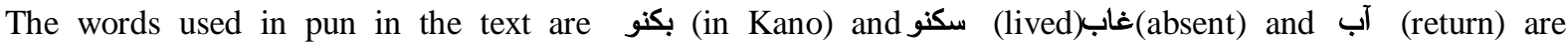
Jināsunghayrutām(incomplete pun)in Arabic rhetoric.

The word - direct and آب (return) is Mashākalah (homonyms) in Arabic rhetoric they are the same words but connote different meanings. This is also a complete puns.

The Sufi style of self-effacing was demonstrated in the poem when he said:

Meaning:

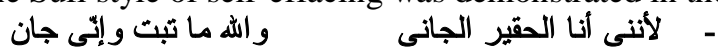

I am a lowly and a sinful servant of Allah, I swear by Allah I have not repented from my sins indeed, (I am) a sinner.

Another illustration for this is the verse:

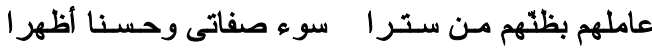

They do not know that they showed interest in a person who Allah covered his anomalies and exposed the good side of him.

The two verses are in the spirit of the meaning of a verse in the Qur'an in which Allah forbids people from praising themselves when Allah says ${ }^{18}$

Meaning:

$$
\text { فلا تزكو ا أنفسكم هو أعلم بمن اتقى }
$$

....so ascribe not purity to yourselves. He knows best who fears Allah and keeps to his duty. ${ }^{19}$

He also employed Tawriyyah (Paronomasia) in his composition by saying:

$$
\text { والظاهز القلب الجميل الظقاهر دحنى باؤل وآخر }
$$

Meaning:

Likewise, (Shaykh Tāhir of Bauchi) a man of clean mind and good body praised me, in the beginning and the end (of his poem)

The word al-Tahir in poem was a disguise as if he said طاهر القلب (a plain minded person). He meant to qualify that Shaykh with the adjective he quickly disguised the quality in his name.

The Sufi doctrine of fear and hope in accordance with the Quranic verse that says ${ }^{20}$

Meaning:

$$
\text { أفآمنو ا مكر الله فلا يأمن مكر الله إلا القوم الخاسرون }
$$

Did they then feel secure against the plan of Allah. None feels secure from the plan of Allah except the people who are lost. ${ }^{21}$

He depicted this fear and hope when he said:

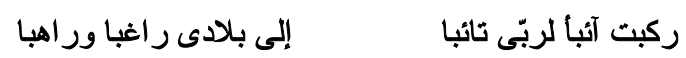


Meaning:

I boarded (in Nigeria) a flight to return to my country while seeking repentance from my Lord in the state of hope and fear.

\section{The Influence of the Poem on TijaniyyahAdherents in Nigeria and West Africa Sufi Scholars}

The poem was regarded as a historical sketch of TijaniyyahSūfi leaders in Nigeria. It is a record which the earlier and contemporary Tijaniyyah order adherents refer to as a compendium of a confirmed Sufi leader who received a rousing welcome from his hosts during his short stay with them. His visit prompted some Tijaniyyah adherents to competitively compose welcoming poems for him which in turn promotes scholarship among the old and young Süfĩ scholars. The visit attracted more followers into the Tijaniyyah order and tend to serve a religious propagative purposes as seen in earlier Muslim travellers. During this visit, some of the followers were elevated to the status of Muqaddam (leader), which served to encourage the spread of the order at their various places as mentioned in lines 53 and 59 of the poem.

In conclusion, it can be said that the influence of the poem on adherent of the Tijaniyyah order cannot be overestimated as the poem served as a source of inspiration to the Tijaniyyah followers and the followers of the Sūfì leaders whose names were mentioned in the poem. The documentation is seen as a bragging right for those mentioned directly or for those whose leaders were mentioned to be authenticated lovers of the Shaykh. The competitiveness exhibited in welcoming him also motivated the youth to come out of their shells to compose poems of welcome to other Sūfi leaders visiting their places, a practice common among Tijanniyah adherents. Such poems include the ones composed for Shaykh UthmanTijāni al-Kanawi (d. 1975) and Khalifal Muhammad Awwal (Omupo), Lagos (d. 2009) among others thereby promoting Arabic literary creativity.

\section{References}

[1] Travel Literature Of The Arabs. Anti Essays. Retrieved fromhttp://www.antiessays.com/free-essays/184802.htmlApril 5, 2012,

[2] Ward A. C (1966). 20th Century English Literature 1901-1960. London: Methuen \& Co., p. 215.

[3] Said E. W (1993). Culture and Imperialism. London: Chatoo\&Windus, p. 24

[4] Sutherland J (1969). English Literature of the Late Seventeenth Century, The Oxford History of English Literature.vol. VI, Eds. BonamyDobrée and Norman Davis. London: Oxford University Press, p. 717

[5] Al-Da'mi M (1986). The Western Variant: The Orient, Orientalism, Literature of the Desert (in Arabic). Baghdad: Cultural Affairs, p.135

[6] Humood Al-Sa'adoon B. K (2002). The Arab East in the eyes of western women: the female response to oriental life with specific reference to Harriet Martineau, Gertrude Bell and Freya Stark. A Masters. Dissertation in the Council of the College of Education for Women, University of Baghdad, p2

[7] El-Shihibi, F. A (2006). Travel genre in Arabic literature: A selective literary and historical study. Dissertation.com, 127pp. Retrieved April 27, 2012 from http://books.google.com.ng/books?id=GBOIIqNA23QC.

[8] Shaykh Ibrahim Abdullahi (1993). Majmū' al-Rihlātush Shaykh Ibrahim. Senegal: Compiled by Shaykh Muhammad al-Amin Nyass

[9] S.A Shittu (2008). Appraisal and Translation of Tabsiratul-'Anam fi anal 'ilmaHuwal-Imam, Mirror to the world: that knowledge is the leader. Ibadan: Tao Publisher, $\mathrm{p} 3$

[10] D.A.A. Tijani (1991): "Sufism in the Arabic Poems of Shaykh Ibrahim Niass al-Kawlakhi", A Ph.D Thesis in the Department of Arabic and Islamic Studies, University of Ibadan, p. 77

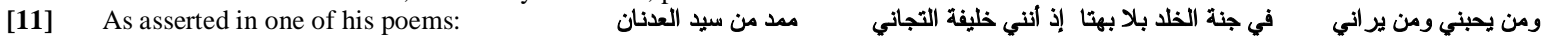

[12] Rules and regulations that authenticate membership of a person being in the Tijaniyyah order and what vitiates his/her oath of allegiance

[13] Ahmad Abil-Fatihibn Ali (n.d): Jawahirur-Rasail al-HawiBa'dUlumWasilatil-wasail. Maiduguri: AbilFathi publishing house, Vol 1 and 2.

[14] Shaykh Ibrahim Abdullahi (1922): Ruhul-AdablimaHawā min HikaminwaAdab. Nigeria: Ibrahim Idris Publisher Funtua, p. 11

[15] One of the highest spiritual ranks in a Sufi order before Allah

[16] Shaykh Gibrima hailed from Nguru, Yobe state, Nigeria , a renowned sufi scholar who has about 40 publications to his credit published in Nigeria and Cairo

[17] al-Qat 'is to delete the silent letter of watadmajmu' in a taf'ilah and change the last letter in the taf'ilah from Harakah to sukün

[18] Qur'an 53:32

[19] al-Hilali M. T and Khan M.M. (1993). The Noble Qur'an in English Language. Riyadh: MaktabahDarul Salam, p. 825

[20] Qur'an 7:99

[21] Ibid. p. 249 
نيل المفازبالعود إلى الحجاز

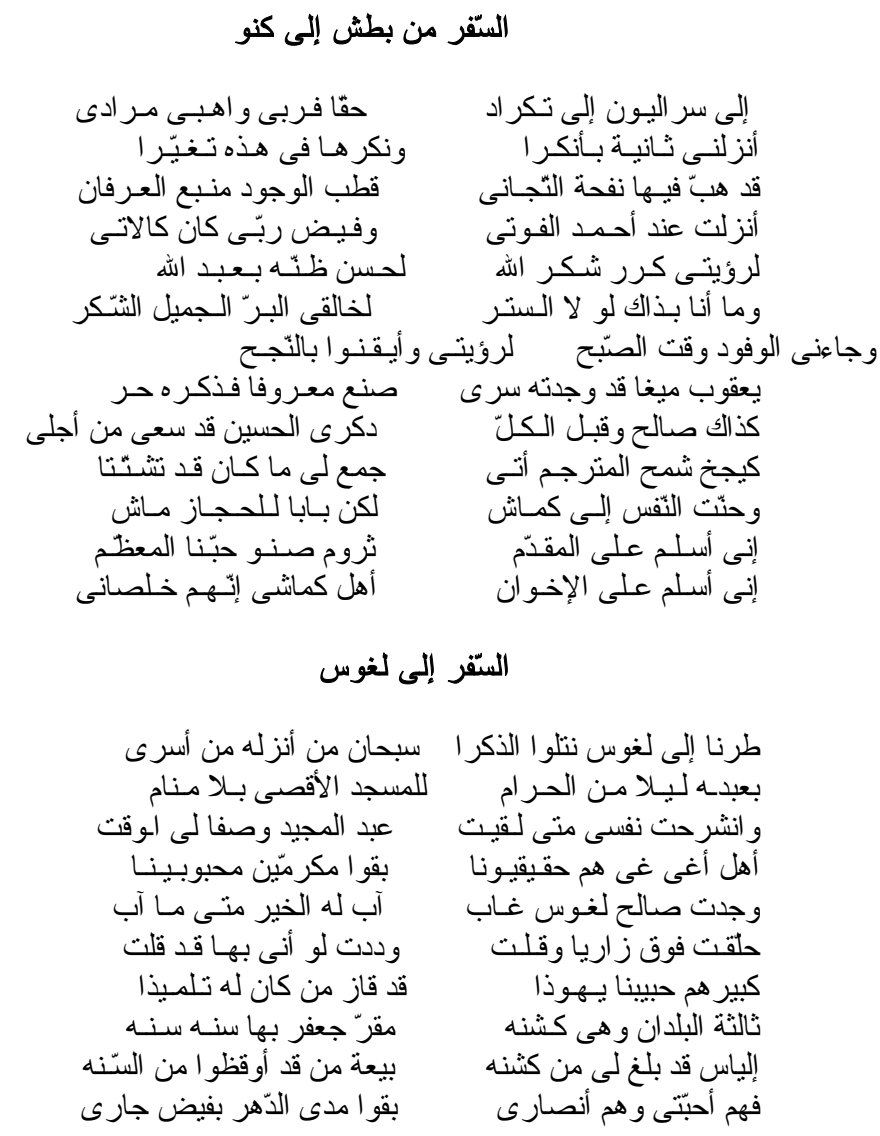

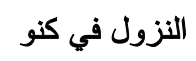

$$
\begin{aligned}
& \text { ما لم يكن - و الله - في حسبانى الهو } \\
& \text { يجرى الأمور كيفما يـر اهـا } \\
& \text { تعنو الـه رقـاب كلّ جهيذ الفيذ }
\end{aligned}
$$

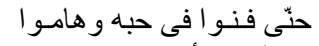

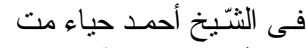

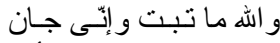

$$
\begin{aligned}
& \text { سو ء صفاتى وحسـنا أظهر التهان } \\
& \text { ثروم اخذا ليس باليسـيـر }
\end{aligned}
$$

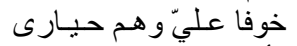

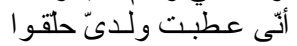

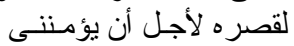

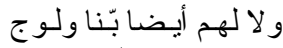

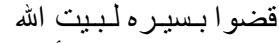

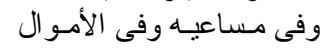

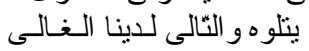

$$
\begin{aligned}
& \text { ودام منـصور ا إلى الآبـاد }
\end{aligned}
$$

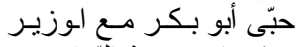

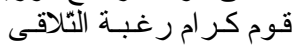

$$
\begin{aligned}
& \text { كفاهــا ربسيّ بـلا وبـؤسيـا }
\end{aligned}
$$

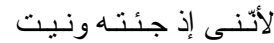$$
\text { بنظرى الموجود كالمعدوم }
$$

حين نز لت ثمّ قد دهـانى

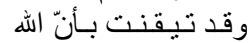
صرت أقول أين ذا الثيخ الذّن الذي

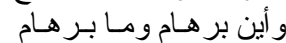

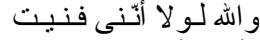

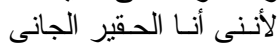

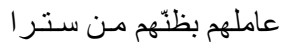
أخذنسى خليفـة الأميـر ردّنى الجيوش و النّصـارى لإنى

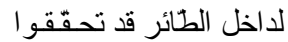

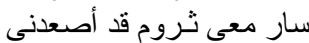

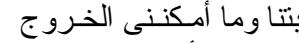
لكنـما الأمبـر عبد الله الهي بورك في الأمير و الـعيال عبد الهيل

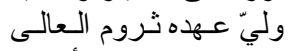

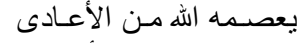
يخدمنى لندمة الأميـر وجاءنى من برنو و المـر اقى لـى

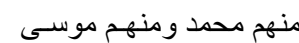
وجئت ما صمت وما صليت موست

الستفر من جدّة إلى كنو راجعا سريت طائر ا إلى الخرطوم 


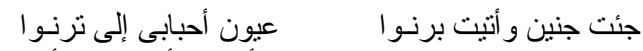

$$
\begin{aligned}
& \text { قد طقت فوق برنو بالطيار أدعون الأحباب بها أخيار } \\
& \text { الرتجوع إلى كنو بعد الحج }
\end{aligned}
$$

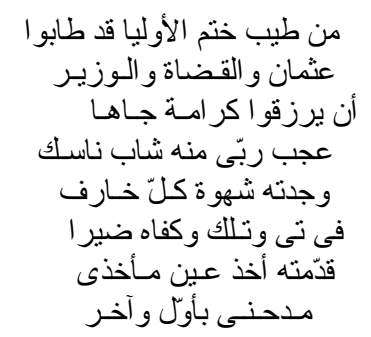

\section{الستقر من كنو إلى كولخ}

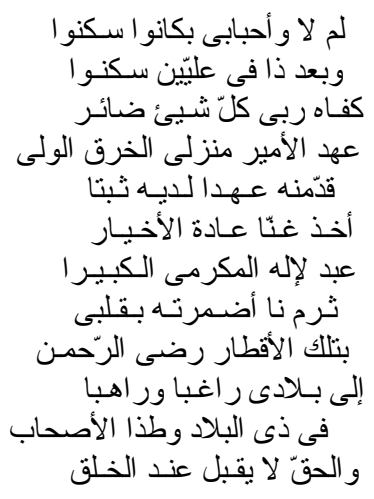

خرجت من كنو وقلبى بكنو

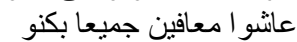

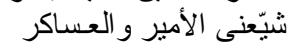

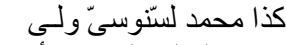

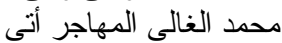

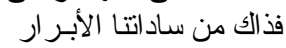

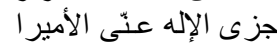

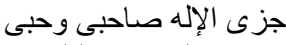

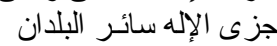
ركبت آئبأ لربّى تائبا فيها مقرّ" الجسم و الأحباب لربّاب أقول حقى للإله الحقّ

المرور بلغوس آثبا

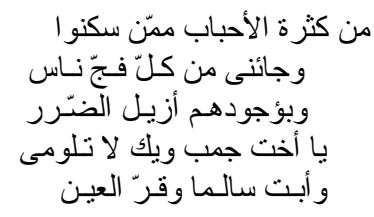

$$
\begin{aligned}
& \text { جئت بعد أنكر و إنّى }
\end{aligned}
$$

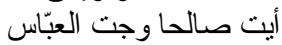

